\title{
Effects of temperature and diet on length-weight relationship and condition factor of the juvenile Malabar blood snapper (Lutjanus malabaricus Bloch \& Schneider, 1801)*
}

\author{
Sabuj Kanti MAZUMDER ${ }^{1}$, Simon Kumar DAS ${ }^{\dagger 1,2}$, Yosni BAKAR ${ }^{1}$, Mazlan Abd. GHAFFAR ${ }^{2,3}$ \\ $\left({ }^{l}\right.$ School of Environmental and Natural Resource Sciences, Faculty of Science and Technology, \\ Universiti Kebangsaan Malaysia, 43600 UKM Bangi Selangor, D.E., Malaysia) \\ ( ${ }^{2}$ Marine Ecosystem Research Center, Faculty of Science and Technology, \\ Universiti Kebangsaan Malaysia, 43600 UKM Bangi, Selangor, D.E., Malaysia) \\ $\left({ }^{3}\right.$ School of Fisheries and Aquaculture Sciences, Universiti Malaysia Terengganu, 21030 Kuala Nerus, Terengganu, Malaysia) \\ †E-mail: simon@ukm.edu.my \\ Received Oct. 15, 2015; Revision accepted Dec. 20, 2015; Crosschecked July 13, 2016
}

\begin{abstract}
In this study we aimed to analyze the effects of water temperature and diet on the length-weight relationship and condition of juvenile Malabar blood snapper Lutjanus malabaricus over a 30-d experimental period. The experiment was conducted in the laboratory using a flow-through-sea-water system. The fish were subjected to four different temperatures $\left(22,26,30\right.$, and $34^{\circ} \mathrm{C}$ ) and two diets (commercial pellet and natural shrimp). Fish were fed twice daily. L. malabaricus exhibited negative allometric growth $(b<3)$ at the beginning of the experiment (Day 0$)$ at all temperatures and both diets except for $22^{\circ} \mathrm{C}$ fed with shrimp, which showed isometric growth $(b=3)$. Conversely, at the end of the experiment (Day 30 ) fish showed isometric growth $(b=3)$ at $30{ }^{\circ} \mathrm{C}$ fed with the pellet diet, indicating that the shape of the fish did not change with increasing weight and length, and a positive allometric growth $(b>3)$ at $30^{\circ} \mathrm{C}$ fed with shrimp diet, which indicated that fish weight increases faster than their length. The rest of the temperatures represented negative allometric growth $(b<3)$ on both diet, meaning that fish became lighter with increasing size. The condition factors in the initial and final measurements were greater than 1 , indicating the state of health of the fish, except for those fed on a pellet diet at $34{ }^{\circ} \mathrm{C}$. However, the best condition was obtained at $30^{\circ} \mathrm{C}$ on both diets. Nevertheless, diets did not have a significant effect on growth and condition of juvenile $L$. malabaricus. The data obtained from this study suggested culturing L. malabaricus at $30^{\circ} \mathrm{C}$ and feeding on the pellet or shrimp diet, which will optimize the overall production and condition of this commercially important fish species.
\end{abstract}

Key words: Length-weight relationship, Condition factor, Temperature, Growth, Aquaculture, Snapper http://dx.doi.org/10.1631/jzus.B1500251

CLC number: S917.4; Q959.4

\section{Introduction}

Among abiotic factors, any change in ambient water temperature has the greatest effect on the

\footnotetext{
Corresponding author

* Project supported by the Ministry of Science Technology and Innovation Malaysia (MOSTI) (No. 04-01-02-SF1208)

(iD ORCID: Simon Kumar DAS, http://orcid.org/0000-0003-0628-9995

(C) Zhejiang University and Springer-Verlag Berlin Heidelberg 2016
}

physiological properties of fish (Johnston, 2006; Arnason et al., 2009; Jun et al., 2012; da Costa et al., 2016; Mazumder et al., 2015b; Zhang et al., 2015). Quite apart from temperature, the quality of food is thought to be another important determinant of fish physiology and ultimately their growth (Kooijman, 2000; Byström et al., 2006; Englund et al., 2011). For most fish species, increases in growth rates with increasing temperatures will be seen, up to a certain 
point, only to decline abruptly once the critical limit of the species is reached (Elliot, 1994; Jobling, 1995). It is plausible, therefore, that fish may choose temperatures that selectively enhance specific physiological processes depending on their state (e.g. fed or unfed, pregnant or immature), time of day and season.

The length-weight relationship (LWR) of fish is important in fisheries and fish biology as it can be used as a characteristic for the differentiation of taxonomic units and the relationship changes with the various developmental events in life such as metamorphosis, growth, and onset of maturity (Mims and Knaub, 1993; Thomas et al., 2003; AlvarezLajonchère, 2012). Furthermore, the empirical relationship between the length and weight of the fish enhances the knowledge of the natural history of commercially important fish species, thus making conservation possible as well as deriving important clues on climate and environmental changes (Sarkar et al., 2013).

The condition factor is a quantitative parameter for the state of well-being of the fish, which will determine present and future population success by its influence on growth, reproduction, and survival (le Cren, 1951). Consequently, the study of condition factors is important for understanding the life cycle of fish species and contributes to satisfactory management of these species and therefore to the maintenance of equilibrium in the ecosystem. Fulton's condition factor $(K)$ is frequently used in the analysis of ontogenetic changes (Safran, 1992) and for betweenregions life-history comparisons (Petrakis and Stergiou, 1995; Simon et al., 2009). Different values in $K$ of a fish indicate the state of sexual maturity, the degree of food source availability, age and sex of some species (Anibeae, 2000). These relationships are also an important component of FishBase (Froese and Pauly, 2012). The relative condition factor $(K n)$ introduced by le Cren (1951) compensates for changes in form or condition with length, and can be used to indicate whether an individual is in a better $(K n>1)$ or worse $(K n<1)$ condition than an average individual with the same length.

Owing to the decline in wild fisheries and sustained consumer demand, the Malabar blood snapper (Lutjanus malabaricus) has been identified as a promising candidate for coastal and marine aquaculture (Nanton et al., 2001; Rosenlund and Skretting,
2006). The development of culture techniques suitable for this species has been on-going for many years in countries such as Malaysia, Thailand, Australia, and Canada (Rosenlund and Skretting, 2006; Treasurer et al., 2006). Larvae and juveniles are typically produced and reared in land-based facilities where conditions can be controlled. However, juveniles must then be transferred to sea-cages where they are exposed to changes in various environmental factors like temperature, food availability, and salinity in Malaysia and these factors have a significant impact on fish appetite (Bendiksen et al., 2002), growth (Brown et al., 1989), and activity (Clark et al., 1995).

Although numerous studies have attempted to determine the simultaneous effects of temperature and diet on the growth or condition in fish, including spotted wolfish Anarhichas minor (Òlafson) (Imsland et al., 2006), cod Gadus morhua (L.) (Bjornsson et al., 2001), turbot Scophthalmus maximus (L.) (Imsland et al., 2007), halibut Hippoglossus hippoglossus (L.) (Hallaraker et al., 1995; Jonassen et al., 1999), plaice Pleuronectes platessa (L.), and flounder Platichthys flesus (L.) (Fonds et al., 1992), adequate local information is still scarce for most tropical and subtropical fish species (Harrison, 2001; Ecoutin et al., 2005). To the best of our knowledge, no information is currently available on the effect of temperature and diet on LWRs and condition factors for this species in Malaysia or elsewhere. The objective of this study was to investigate the effects of temperature and diet on LWRs and condition factors of the Malabar blood snapper (L. malabaricus) in laboratory conditions.

\section{Materials and methods}

\subsection{Experimental setup}

A homogeneous group (6-7 cm) of L. malabaricus $(n=120)$ was collected from local hatcheries of Pulau Ketam, Klang coast $\left(3^{\circ} 00^{\prime} 96.2^{\prime \prime} \mathrm{N}\right.$ to $2^{\circ} 00^{\prime} 91.8^{\prime \prime} \mathrm{N}$ and $101^{\circ} 16^{\prime} 38.2^{\prime \prime} \mathrm{E}$ to $101^{\circ} 16^{\prime} 49.5^{\prime \prime} \mathrm{E}$ ), Selangor, peninsular Malaysia, and transported to the marine science laboratory of UKM Bangi, Malaysia. The fish were housed in several stocking tanks $(1.96 \mathrm{~m} \times 1.02 \mathrm{~m} \times$ $0.61 \mathrm{~m}, 1200 \mathrm{~L}$ ) for up to five days at room temperature (about $\left.26^{\circ} \mathrm{C}\right)$ and salinity $\left(30 \mathrm{ppt}\left(1 \mathrm{ppt}=10^{-12}\right)\right.$ ), and on food used in the hatcheries. Once the fish 
started feeding and defecating, they were transferred into four experimental tanks and were reared at four different temperatures $\left(22,26,30\right.$, and $\left.34^{\circ} \mathrm{C}\right)$. Each tank comprised two compartments (15 fish/compartment). The partition separating the compartment was made of plexi glass with holes to ensure similar water temperature across the compartment. The fish were fed twice daily (9:00 and 16:00) with demand feeding with a commercial diet pellet (protein $45 \%-47 \%$, lipid $8 \%$, and carbohydrate $7 \%$ ) and natural diet shrimps (Acetes sp. protein $57.55 \%$, lipid $7.56 \%$, and carbohydrate $7.54 \%$ ). The temperature changes for the experimental groups were initiated at a rate of $2{ }^{\circ} \mathrm{C} / \mathrm{d}$ using thermostat (E-JET heater $200 \mathrm{~W}$, Penang, Malaysia) and chiller (HS-28 A, 250-1200L/H, Guangdong Hailea Group Co., Ltd., Country of Origin, China) until the experimental temperature was reached, a minimum of $22{ }^{\circ} \mathrm{C}$ and a maximum of $34{ }^{\circ} \mathrm{C}$. The fish were then deprived of food for two days and anesthetized with $\alpha$-methyl quinoline (TransmoreR; Nika Trading, Puchong, Malaysia; $0.22 \mathrm{ml} / \mathrm{L}$ in $3 \mathrm{~L}$ of sea water as an aneasthetic medium for 10-15 $\mathrm{min}$ ) prior to the initial measurement of total length $(\mathrm{cm})$ and body weight $(\mathrm{g})$. The total length was measured to the nearest $0.01 \mathrm{~cm}$ with a measuring board (Simon et al., 2010a) and weighed to the nearest $0.01 \mathrm{~g}$ (Simon et al., 2010b) using an electronic balance Model KD-300KC (Simon et al., 2012). After the starvation period, the fish were fed to satiation (Das et al., 2014b; Mazumder et al., 2015a) and offered two different diets, pellet or shrimp (four compartments for pellet and four compartments for shrimp), the leftovers after 2 min of feeding. The temperatures were measured daily. The duration of the experiments was $30 \mathrm{~d}$ for each temperature to keep the relative length and weight increase of similar magnitude in all the experiments. During this experimental period, fish were maintained on a $12-\mathrm{h}$ light:12-h dark photoperiod and fed twice daily.

\subsection{Length-weight relationship}

The LWR in the present study was calculated using the following equation (Froese, 2006):

$$
W=a L^{b},
$$

where $W$ is the weight of fish (g), $L$ is the length of fish (cm), $a$ is the intercept of the regression, and $b$ is an exponential expressing the relationship between length and weight. When $b=3$, the increase in weight is isometric. When the value of $b$ is other than 3 , weight increase is allometric (positive if $b>3$, negative if $b<3$ ).

\subsection{Condition factors}

The Fulton's condition factor $K$ was calculated for each individual fish according to Fulton (1904):

$$
K=100 \mathrm{~W} / \mathrm{L}^{3}
$$

while relative condition factor $K n$ was calculated according to le Cren (1951):

$$
K n=W\left(a L^{b}\right)^{-1},
$$

where $W$ is the body weight (BW), $L$ is the total length (TL), $a$ is the intercept, $b$ is the slope, and 100 is a factor to bring the value of $K$ near unity.

\subsection{Statistical analyses}

Determination of $a$ and $b$ values was performed using a non-linear regression of which the curve fitting was carried out by Chi-square $\left(\chi^{2}\right)$ iterative methods using Levenberg-Marquardt and Simplex algorithms readily developed in Microcalc Origin ${ }^{\mathrm{TM}}$ Version 9.0 computer software (Das et al., 2014a). The measurement of model fit (goodness of fit of calculated TL and BW) was evaluated by the coefficient of determination $\left(r^{2}\right)$. For each temperature and diet, the Student's $t$-test (Zar, 1996) was performed on the slope of $\operatorname{logBW}-\log \mathrm{TL}$ to test whether the computed value of $b$ was significantly different from 3, indicating the type of growth. Additionally, the analysis of covariance (ANCOVA) was also applied to evaluate the homogeneity of the regression slopes between initial measurement (IM, Day 0) and final measurement (FM, Day 30) at each temperature and diet whereby $\log \mathrm{BW}$ was modelled as a function of stage (IM or FM), and $\log$ TL as covariate and their interaction. The interaction term was tested for homogeneity of the slopes. To determine the effects of temperature and stage (IM or FM) on condition factors ( $K$ and $K n$ ) of the Malabar blood snappers fed on either pellet or shrimp diets, a two-factor factorial model was initially used. When significant temperature $\times$ stage interactions were encountered, the cell means were 
analyzed in a one-factor linear model. To determine differences among the experimental groups within each diet, Tukey post-hoc tests were used. Statistical analyses were performed using Minitab Version 17 (StatSoft Inc., Tulsa, OK, USA).

\section{Results}

\subsection{Length-weight relationship}

Results obtained for the LWRs from $120 \mathrm{~L}$. malabaricus fish at different temperatures and diets are given in Table 1 and Fig. 1. TLs and BWs of the samples ranged from 6-7 $\mathrm{cm}$ and $4-8 \mathrm{~g}$, respectively. The nonlinear fit of LWR of L. malabaricus is presented in Fig. 1, whereas Table 1 presents the regression coefficients $b$ of the log-transformed variables and the growth type of samples. In terms of growth type, the $L$. malabaricus showed a negative allometric growth $(b<3)$ in initial measurements (IM, Day 0) at all experimental temperatures and diets except the shrimp diet at $22{ }^{\circ} \mathrm{C}(b=3.09 ; P<0.05, d f=13$, standard error $(\mathrm{SE})=0.09)$, which indicated that the fish became lighter with increasing size. A similar growth pattern was also observed in final measurements (FM, Day 30) at all the temperatures and both diets except $30{ }^{\circ} \mathrm{C}$ and both diets. On the contrary in FM, the fish exhibited an isometric growth $(b=3.02)$ on being fed the pellet $\operatorname{diet}(P>0.05, d f=13$, $\mathrm{SE}=0.19)$ at $30^{\circ} \mathrm{C}$, thereby indicating that the shape of the fish did not change with increasing weight and length. At $30{ }^{\circ} \mathrm{C}$ for shrimp-fed fish, a positive allometric growth $(b>3)$ was observed $(P>0.05, d f=13$, $\mathrm{SE}=0.12$ ), indicating that the fish became heavier as they increased in length and size. The exponent $b$ ranged from $2.10 \pm 0.14$ with pellet diet at $34{ }^{\circ} \mathrm{C}$ to $3.20 \pm 0.17$ for $30^{\circ} \mathrm{C}$, and in shrimp diet the $b$ values ranged from $2.17 \pm 0.17$ at $34^{\circ} \mathrm{C}$ to $3.20 \pm 0.17$ at $30^{\circ} \mathrm{C}$, corresponding to a mean value of $2.60 \pm 0.38$ and $2.75 \pm 0.38$ at $P<0.05$ with pellet and shrimp diet, meaning that all LWR slopes $(b)$ were within the expected ranges $(2.0<b<4.0)$ (Bagenal and Tesch, 1978).

ANCOVA showed significant differences between the slopes of IM and FM only at $22{ }^{\circ} \mathrm{C}$ and the shrimp diet, whereas no significance differences were observed at other temperatures and diets (Table 1). The regression models fitting in IM and FM of L. malabaricus were highly correlated $\left(r^{2}=0.811-\right.$ 0.977).

\subsection{Condition factor analysis}

Two-way ANOVA indicated that the interaction of temperature and stage was statistically significant $(P<0.001)$ for condition factors. Therefore, pairwise comparisons of the cell means were performed instead.

The mean condition factors $(K$ and $K n)$ for the four experimental temperatures with the two different diets of L. malabaricus are presented in Fig. 2. In the

Table 1 Regression coefficients of length-weight relationships of $L$. malabaricus fed different diets at four different temperatures

\begin{tabular}{|c|c|c|c|c|c|c|c|c|c|}
\hline \multirow{3}{*}{$\begin{array}{c}T \\
\left({ }^{\circ} \mathrm{C}\right)\end{array}$} & \multirow{3}{*}{ Diet } & \multicolumn{2}{|c|}{ Regression coefficient $(b)$} & \multicolumn{2}{|c|}{ Type of growth } & \multicolumn{4}{|c|}{ Status of wellbeing } \\
\hline & & \multirow{2}{*}{ IM } & \multirow{2}{*}{ FM } & \multirow{2}{*}{ IM } & \multirow{2}{*}{ FM } & \multicolumn{2}{|c|}{ IM } & \multicolumn{2}{|c|}{ FM } \\
\hline & & & & & & $K$ & $K n$ & $K$ & $K n$ \\
\hline \multirow[t]{2}{*}{22} & Pellet & $2.70 \pm 0.15$ & $2.38 \pm 0.17$ & $-\mathrm{A}$ & $-\mathrm{A}$ & $1.90 \pm 0.07^{\mathrm{G}}$ & $1.021 \pm 0.040^{\mathrm{G}}$ & $1.90 \pm 0.18^{\mathrm{G}}$ & $1.001 \pm 0.060^{\mathrm{G}}$ \\
\hline & Shrimp & $3.09 \pm 0.12^{*}$ & $2.70 \pm 0.12$ & I & $-\mathrm{A}$ & $1.82 \pm 0.05^{\mathrm{G}}$ & $1.002 \pm 0.030^{\mathrm{G}}$ & $1.81 \pm 0.14^{\mathrm{G}}$ & $1.006 \pm 0.060$ \\
\hline \multirow[t]{2}{*}{26} & Pellet & $2.52 \pm 0.14$ & $2.90 \pm 0.25$ & $-\mathrm{A}$ & $-\mathrm{A}$ & $1.18 \pm 0.08^{\mathrm{G}}$ & $1.000 \pm 0.030^{\mathrm{G}}$ & $2.03 \pm 0.16^{\mathrm{G}}$ & $1.009 \pm 0.080$ \\
\hline & Shrimp & $2.51 \pm 0.18$ & $2.92 \pm 0.19$ & $-\mathrm{A}$ & $-\mathrm{A}$ & $1.80 \pm 0.08^{\mathrm{G}}$ & $0.990 \pm 0.040^{\mathrm{B}}$ & $2.10 \pm 0.16^{\mathrm{G}}$ & $1.011 \pm 0.070^{\mathrm{G}}$ \\
\hline \multirow[t]{2}{*}{30} & Pellet & $2.70 \pm 0.26$ & $3.02 \pm 0.20$ & $-\mathrm{A}$ & I & $1.78 \pm 0.11^{\mathrm{G}}$ & $1.002 \pm 0.060^{\mathrm{G}}$ & $2.10 \pm 0.21^{\mathrm{G}}$ & $1.009 \pm 0.100^{\mathrm{G}}$ \\
\hline & Shrimp & $2.50 \pm 0.12$ & $3.20 \pm 0.17$ & $-\mathrm{A}$ & $+\mathrm{A}$ & $1.77 \pm 0.08^{\mathrm{G}}$ & $1.000 \pm 0.030^{\mathrm{G}}$ & $1.99 \pm 0.15^{\mathrm{G}}$ & $1.021 \pm 0.090^{\mathrm{G}}$ \\
\hline \multirow[t]{2}{*}{34} & Pellet & $2.21 \pm 0.26$ & $2.10 \pm 0.14$ & $-\mathrm{A}$ & $-\mathrm{A}$ & $1.82 \pm 0.15^{\mathrm{G}}$ & $1.001 \pm 0.050^{\mathrm{G}}$ & $1.79 \pm 0.15^{\mathrm{G}}$ & $0.998 \pm 0.050^{\mathrm{B}}$ \\
\hline & Shrimp & $2.21 \pm 0.26$ & $2.17 \pm 0.17$ & $-\mathrm{A}$ & $-\mathrm{A}$ & $1.82 \pm 0.25^{\mathrm{G}}$ & $1.006 \pm 0.080^{\mathrm{G}}$ & $1.73 \pm 0.20^{\mathrm{G}}$ & $1.000 \pm 0.070^{\mathrm{G}}$ \\
\hline
\end{tabular}

The type of growth is inferred from the regression coefficient $(b)$ value. $K$ and $K n$ represent Fulton and relative condition factors (Sample size for each diet-temperature combination). Data are express as mean \pm standard error (SE), $n=15$. $-\mathrm{A}$ : negative allometric growth; + A: positive allometric growth; I: isometric growth; IM: initial measurement; FM: final measurement; ${ }^{\mathrm{G}}$ : good condition; ${ }^{\mathrm{B}}$ : poor condition. ${ }^{*} P<0.05$, significant difference between initial and final LWRs 

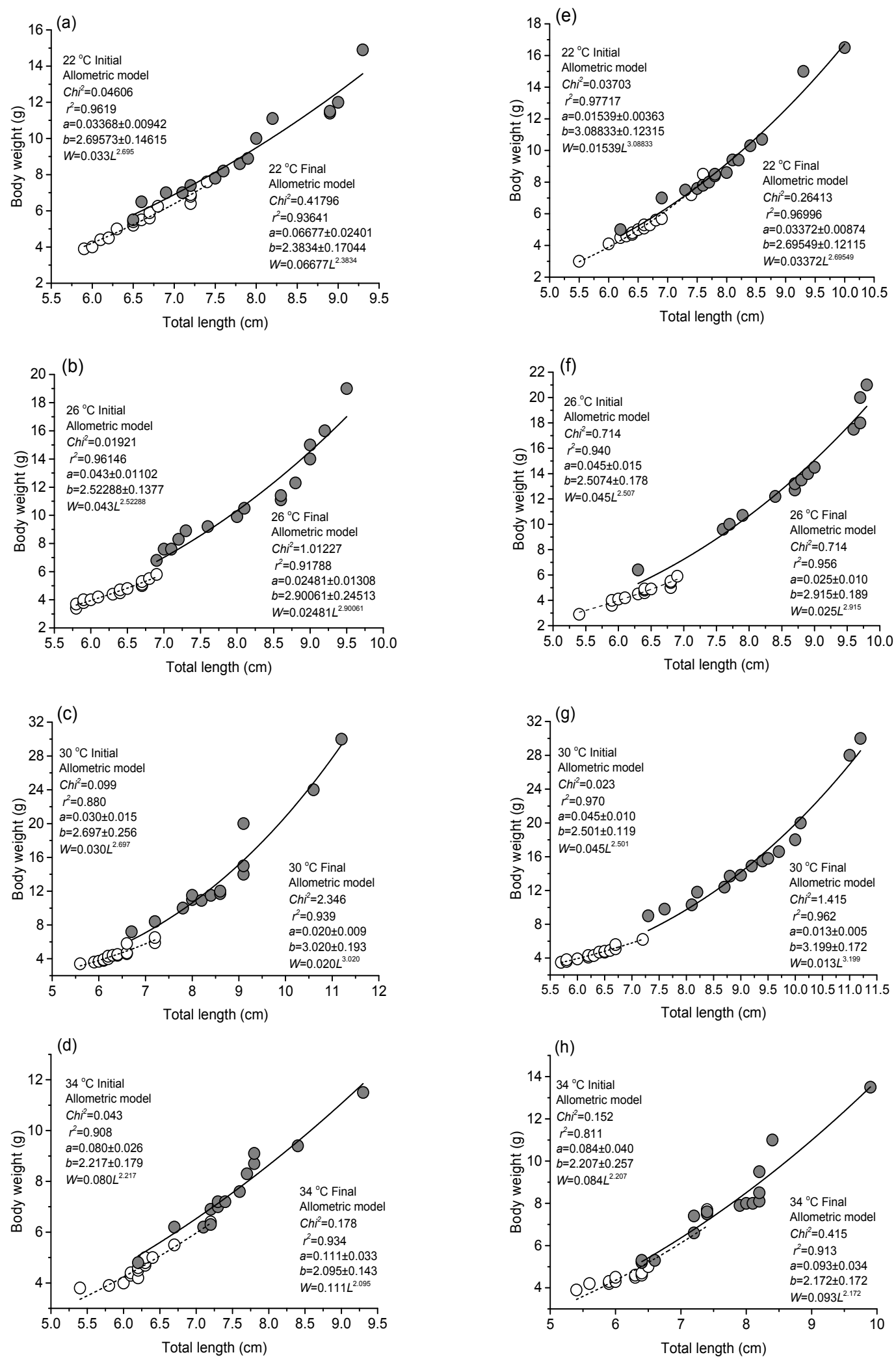

Fig. 1 Length-weight relationship of $L$. malabaricus fed on pellet (a-d) and shrimp (e-h) diets

Dashed line represents initial (Day 0) and solid line represents final (Day 30) nonlinear fit whereas open and solid circles represent individual fish samples 

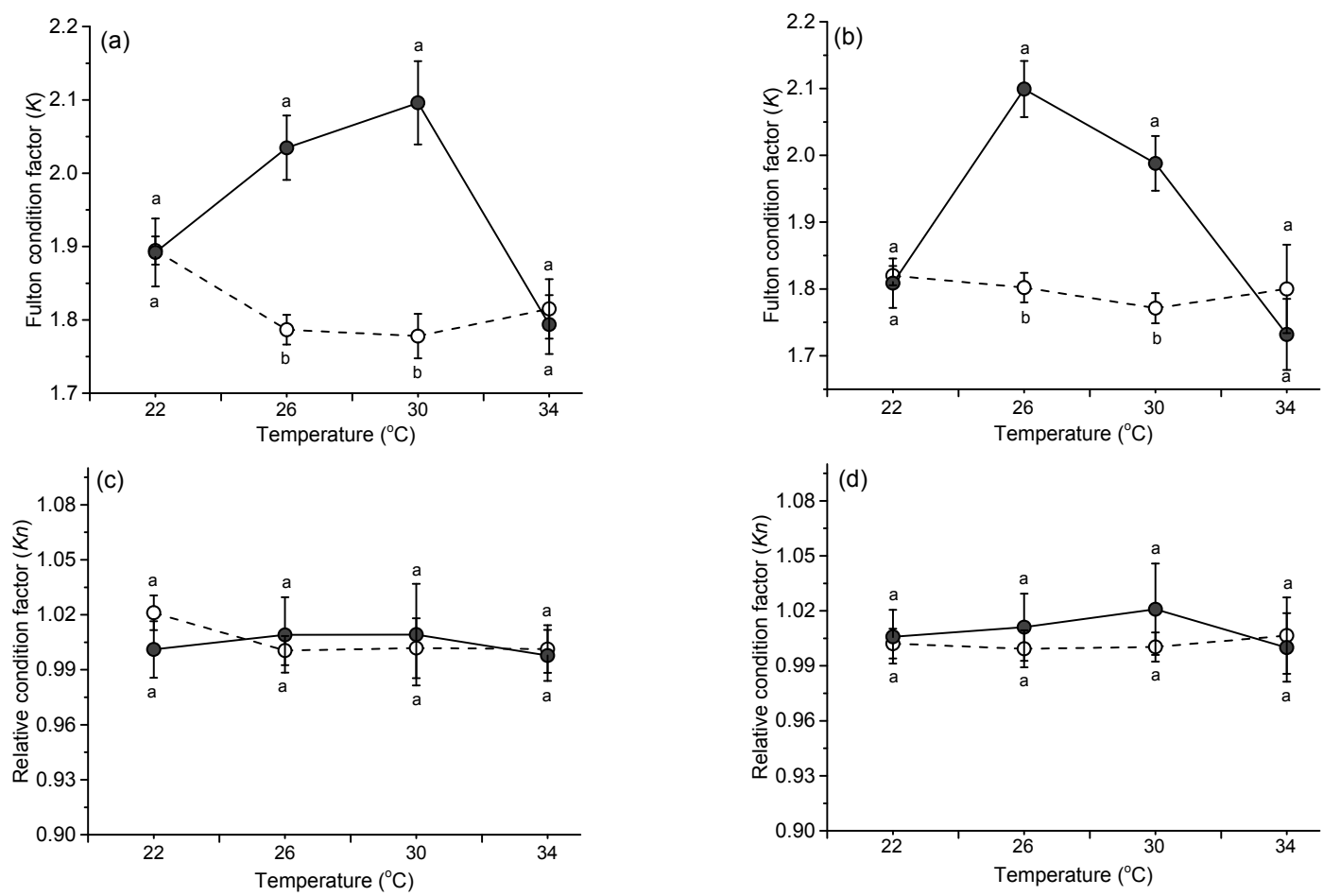

Fig. 2 Mean Fultons $(K)$ and relative condition factors $(K n)$ with pellet feeding (a, c) and shrimp feeding (b, d) at four different temperatures

Dashed line represents initial measurement (Day 0) and solid line represents final measurement (Day 30). Open circles represent initial mean values of $K$ and $K n$ and solid circles represent final mean values of $K$ and $K n$. Solid bar denotes variant of $K$ and $K n$ values with different alphabets differing significantly

present study, the condition factors $K$ varied from 1.73 to 1.90 in IM and 1.73 to 2.10 in FM and $K n$ from 0.990 to 1.020 and 0.998 to 1.020 in IM and FM, respectively. The $K$ and $K n$ values registered a significant and progressive increase $(P<0.05)$ in IM with increasing temperature from 22 to $30^{\circ} \mathrm{C}$ and slowed down gradually with increasing further temperature to $34{ }^{\circ} \mathrm{C}$ (Fig. 2). Conversely in FM, $K$ values were significantly lower at $34{ }^{\circ} \mathrm{C}$ but not significantly $(P>0.05)$ and feeding with pellet diet. Similarly in FM, the $K n$ values were also lower at $34{ }^{\circ} \mathrm{C}$ and higher at 26 and $30^{\circ} \mathrm{C}(P>0.05)$, indicating poor and good fish conditions, respectively.

\section{Discussion}

In the present study, the length-weight data were considered to establish the growth form of L. malabaricus at different temperatures and diet. Lagler (1966) and Wootton (1990) suggested that if fish grow isometrically, they retain body shape, and specific gravity will also remain unchanged during the life time; therefore, in such cases, the $b$-value must be equal to 3.0. Hence, this growth pattern in fish will follow the cube law. However, under natural conditions, most fish do not show the cube law, because they change their body shape as they grow or increase in size and become heavier in one season and lighter in another. Hence, le Cren (1951) reported that the relationship between length and weight of fish may depart from the ideal value (3.0), which may be due to certain environmental conditions or the condition of the fish themselves. Therefore, the $b$-value for each fish species could be significantly greater or less than the ideal value, indicating that growth pattern is allometric (Gayanilo and Pauly, 1997). Thus, if the $b$-value is equal to 3.0 , growth is isometric, but if the $b$-value is less than 3.0 , fish become more slender as they increase in length; therefore, growth will be negatively allometric, which might be because habitat conditions are not suitable for growth. On the other hand, if the $b$-value is greater than 3.0, fish become heavier and show a positive allometric pattern of growth for their specific lengths, which may be due to optimum conditions (Abowei, 2010). 
In this study, we observed that L. malabaricus exhibited negative allometric growth $(b<3)$ at the start of the experiment (Day 0) at all the temperatures and diets except for $22^{\circ} \mathrm{C}$ and a shrimp diet, which showed isometric growth $(b=3)$. In $\mathrm{FM}$ at $30{ }^{\circ} \mathrm{C}$ a positive allometric growth $(b>3)$ and an isometric growth $(b=3)$ were found on shrimp and pellet diets, respectively. The rest of the temperatures and diets showed negative allometric growth $(b<3)$. The LWRs of L. malabaricus raised in similar temperatures and diets have not been previously recorded in Malaysia or elsewhere, thereby preventing a direct comparison with earlier results. Masood and Farooq (2010) observed LWRs in different sexes of $L$. malabaricus and found positive allometric growth $(b>3)$ in Pakistan waters, which is in agreement with $30^{\circ} \mathrm{C}$ and shrimp diet in FM (Day 30). Alternatively, Willing and Pender (1989) found negative allometric growth $(b<3)$ in juveniles of the same species in Australia, which is also similar to our findings both in IM and FM. However, we compared our results with the studies dealing with the Lutjanus species from different geographical locations (Table 2).

Table 2 Regression coefficients for length-weight relationships in $L$. malabaricus tested with different temperatures and diets compared with other Lutjanus species in previous studies

\begin{tabular}{|c|c|c|c|c|c|c|c|c|}
\hline \multirow{2}{*}{ Reference } & \multirow{2}{*}{ Species } & \multirow{2}{*}{ Sex } & \multicolumn{3}{|c|}{ LWR parameter } & \multirow{2}{*}{$\begin{array}{c}\text { Growth } \\
\text { type }\end{array}$} & \multirow{2}{*}{ Temp } & \multirow{2}{*}{ Locality } \\
\hline & & & $a$ & $b$ & $r^{2}$ & & & \\
\hline Pakoa, 1998 & L. argentimaculatus & Unsexed & 0.0054 & 3.206 & & $+\mathrm{A}$ & & Vanuatu \\
\hline Joyeux et al., 2009 & L. analis & Juvenile & 0.0163 & 2.944 & 0.996 & $-\mathrm{A}$ & & Brazil \\
\hline Burton, 2002 & L. analis & Unsexed & 0.0113 & 3.050 & 0.960 & I & & USA \\
\hline Yanagawa, 1994 & L. lutjanus & Unsexed & 0.0235 & 2.807 & 0.891 & $-\mathrm{A}$ & & Thailand \\
\hline \multirow[t]{3}{*}{ Masood and Farooq, 2010} & L. lutjanus & Male & 0.0110 & 3.210 & 0.993 & $+\mathrm{A}$ & & Pakistan \\
\hline & & Female & 0.0960 & 2.530 & 0.876 & $-\mathrm{A}$ & & \\
\hline & & Combined sex & 0.0210 & 3.010 & 0.991 & I & & \\
\hline Crawford, 1993 & L. argentiventris & Unsexed & 0.0173 & 3.000 & & I & & Mexico \\
\hline \multirow[t]{2}{*}{ Blanco et al., 2003} & L. gibbus & Unsexed & 0.0400 & 2.580 & 0.889 & $-\mathrm{A}$ & & Spain \\
\hline & & Unsexed & 0.0420 & 2.680 & 0.859 & $-\mathrm{A}$ & & \\
\hline \multirow[t]{3}{*}{ Masood and Farooq, 2010} & L. johnii & Male & 0.0810 & 2.790 & 0.946 & $-\mathrm{A}$ & & \\
\hline & & Female & 0.0170 & 3.310 & 0.986 & $+\mathrm{A}$ & & Pakistan \\
\hline & & Combined sex & 0.0120 & 3.370 & 0.925 & $+\mathrm{A}$ & & \\
\hline \multirow[t]{3}{*}{ Masood and Farooq, 2010} & L. russelii & Male & 0.0100 & 3.150 & 0.998 & $+\mathrm{A}$ & & \\
\hline & & Female & 0.0070 & 3.270 & 0.994 & $+\mathrm{A}$ & & Pakistan \\
\hline & & Combined sex & 0.0090 & 3.170 & 0.992 & $+\mathrm{A}$ & & \\
\hline \multirow[t]{3}{*}{ Masood and Farooq, 2010} & L. fulvus & Male & 0.0650 & 2.580 & 0.994 & $-\mathrm{A}$ & & \\
\hline & & Female & 0.0070 & 3.270 & 0.996 & $+\mathrm{A}$ & & Pakistan \\
\hline & & Combined sex & 0.0280 & 2.840 & 0.972 & $-\mathrm{A}$ & & \\
\hline \multirow[t]{3}{*}{ Masood and Farooq, 2010} & L. fulvus & Male & 0.0020 & 3.840 & 0.997 & $+\mathrm{A}$ & & \\
\hline & & Female & 0.0070 & 3.530 & 0.992 & $+\mathrm{A}$ & & Pakistan \\
\hline & & Combined sex & 0.0030 & 3.630 & 0.986 & $+\mathrm{A}$ & & \\
\hline Willing and Pender, 1989 & L. fulvus & Juvenile & 0.0313 & 2.872 & 0.994 & $-\mathrm{A}$ & & Australia \\
\hline \multirow[t]{8}{*}{ Present study (IM) } & L. malabaricus & Juvenile & $0.0334^{*}$ & $2.696^{*}$ & $0.962^{*}$ & $-\mathrm{A}$ & S & Malaysia \\
\hline & & & $0.0150^{* *}$ & $3.088^{* *}$ & $0.977^{* *}$ & & $\mathrm{~S}$ & \\
\hline & & & $0.0430^{*}$ & $2.523^{*}$ & $0.962^{*}$ & $-\mathrm{A}$ & $\mathrm{T}$ & \\
\hline & & & $0.0450^{* *}$ & $2.507^{* *}$ & $0.940^{* *}$ & $-\mathrm{A}$ & $\mathrm{T}$ & \\
\hline & & & $0.0300^{*}$ & $2.697^{*}$ & $0.880^{*}$ & $-\mathrm{A}$ & $\mathrm{U}$ & \\
\hline & & & $0.0450^{* *}$ & $2.501^{* *}$ & $0.097^{* *}$ & $-\mathrm{A}$ & $\mathrm{U}$ & \\
\hline & & & $0.0800^{*}$ & $2.217^{*}$ & $0.908^{*}$ & $-\mathrm{A}$ & $\mathrm{V}$ & \\
\hline & & & $0.0840^{* *}$ & $2.207^{* *}$ & $0.811^{* *}$ & $-\mathrm{A}$ & $\mathrm{V}$ & \\
\hline \multirow[t]{8}{*}{ Present study (FM) } & L. malabaricus & Juvenile & $0.0670^{*}$ & $2.383^{*}$ & $0.936^{*}$ & $-\mathrm{A}$ & S & Malaysia \\
\hline & & & $0.0340^{* *}$ & $2.696^{* *}$ & $0.970^{* *}$ & $-\mathrm{A}$ & S & \\
\hline & & & $0.0250^{*}$ & $2.901^{*}$ & $0.918^{*}$ & $-\mathrm{A}$ & $\mathrm{T}$ & \\
\hline & & & $0.0250^{* *}$ & $2.915^{* *}$ & $0.956^{* *}$ & $-\mathrm{A}$ & $\mathrm{T}$ & \\
\hline & & & $0.0200^{*}$ & $3.020^{*}$ & $0.939^{*}$ & I & $\mathrm{U}$ & \\
\hline & & & $0.0130^{* *}$ & $3.200^{* *}$ & $0.962^{* *}$ & $+\mathrm{A}$ & $\mathrm{U}$ & \\
\hline & & & $0.1110^{*}$ & $2.095^{*}$ & $0.934^{*}$ & $-\mathrm{A}$ & V & \\
\hline & & & $0.0930^{* *}$ & $2.172^{* *}$ & $0.913^{* *}$ & $-\mathrm{A}$ & V & \\
\hline
\end{tabular}

\footnotetext{
${ }^{*}$ Pellet diet; ${ }^{* *}$ Shrimp diet; IM: initial measurement; FM: final measurement; $-\mathrm{A}$ : negative allometric growth; +A: positive allometric growth;
} I: isometric growth; Temp: temperature; S: $22{ }^{\circ} \mathrm{C} ; \mathrm{T}: 26^{\circ} \mathrm{C} ; \mathrm{U}: 30^{\circ} \mathrm{C} ; \mathrm{V}: 34^{\circ} \mathrm{C}$ 
The fish were collected from a local land-based hatchery where the temperature was maintained at $26{ }^{\circ} \mathrm{C}$. However, in most cases, the L. malabaricus that were reared in marine and brackish water cages and were exposed to higher temperature ranges could demonstrate a positive allometric growth. In addition, a higher temperature could increase the metabolic rates of fish (Temming and Herrmann, 2001), thereby accelerating their digestion process (De et al., 2013) and inducing better (isometric and positive allometric) growth.

Temperature and diet interacted to determine the growth in $L$. malabaricus. The species performed better when temperatures increased from lower to higher up to their optimum and on feeding with a natural shrimp than with pellet diet. Overall growth rate was highest at $30^{\circ} \mathrm{C}$ and feeding with a shrimp diet. The growth rate in the shrimp-fed group being higher than with the pellet-fed group might be due to the fact that the Malabar blood snapper consumed more shrimp than pellet food (personal observation) because of the pellet's hard and compact structure. Moreover, the shrimp contains more protein than the pellet diet, which helps to gain more and represent better growth performance.

Increasing $K$ and $K n$ values were observed in FM at 26 and $30{ }^{\circ} \mathrm{C}$ (i.e., better condition), whereas decreasing $K$ and $K n$ values were observed at 34 and $22{ }^{\circ} \mathrm{C}$ (i.e., poorer condition) regardless of diet (Fig. 2). The growth rates achieved in this work may be considered acceptable in comparison with those reported in other similar studies for L. peru (GarduñoDionate et al., 2010; Castillo-Vargasmachuca et al., 2012; 2013) and for L. argentiventris and L. aolorado in the wild (Santamaría-Miranda et al., 2003). The experimental results indicated that $L$. malabaricus may adjust to gradual temperature increments. At $22{ }^{\circ} \mathrm{C}$, visceral fat was crucial for the survival of seldom-fed fish (Braga, 1986). Braga (1986) and Oni et al. (1983) showed that the values of the condition factor could vary across different seasons and could be influenced by biotic and abiotic factors. The radical change in temperature from 26 to $22{ }^{\circ} \mathrm{C}$ and to $34{ }^{\circ} \mathrm{C}$ could be attributed to such differences in conditions. The $K$ and $K n$ values did not significantly vary in IM, which could be attributed to the short dwelling time and short temperature ranges for the shrimp- and pellet-fed fish (Helmuth et al., 2010).
Masood and Farooq (2010) had reported the Kn values for combined sexes of five Lutjanus species including $L$. johnii, L. lutjanus, L. malabaricus, $L$. russellii, and L. fulvus as 1.46, 1.01, 1.0, 0.44, and 1.0, respectively, which are also in agreement with the findings of the present study. To the best of our knowledge, no references dealing with temperature effects on LWRs or condition factors for the studied species are available, thereby preventing a direct comparison of our findings with previous results. However, to reach a more definite conclusion, similar studies should be conducted with different life stages of L. malabaricus.

\section{Conclusions}

This study provides the first basic and baseline information on the temperature and diet effects on LWR and condition of L. malabaricus. These variables are important when evaluating the physiological status of the species. Overall, it is possible to conclude that a temperature of $30^{\circ} \mathrm{C}$ is the optimum for growth and condition of L. malabaricus when feeding on a natural shrimp diet. These findings would be beneficial for the snapper aquaculture industry to improve the growth of L. malabaricus, and also may be helpful for fishery biologists and sustainable fishery management to cope with the global warming and conservation of biodiversity for not only the Malaysian waters but also in other parts of the world.

\section{Acknowledgements}

We appreciate the anonymous reviewers for their meticulous comments that greatly improved the quality of the manuscript.

\section{Compliance with ethics guidelines}

Sabuj Kanti MAZUMDER, Simon Kumar DAS, Yosni BAKAR, and Mazlan Abd. GHAFFAR declare that they have no conflict of interest.

All institutional and national guidelines for the care and use of laboratory animals were followed.

\section{References}

Abowei, J.F.N., 2010. The condition factor, length-weight relationship and abundance of Ilisha africana (Block, 1795) from Nkoro River Niger Delta, Nigeria. $A d v . J$. Food Sci. Tech., 2:6-11.

Alvarez-Lajonchère, L., 2012. Relationships of maximum 
length, length at first sexual maturity, and growth performance index in nature with absolute growth rates of intensive cultivation of some tropical marine fish. $J$. World Aquacult. Soc., 43(5):607-620.

http://dx.doi.org/10.1111/j.1749-7345.2012.00591.x

Anibeae, C.I.P., 2000. Length-weight relationship and relative condition of Heterobranchus longifilis (Valencienness) from Idodo River, Nigeria. Naga, ICLARM Q., 23(2):34-35.

Arnason, T., Bjornsson, B., Steinarsson, A., 2009. Allometric growth and condition factor of Atlantic cod (Gadus morhua) fed to satiation: effects of temperature and body weight. J. Appl. Ichthyol., 25(4):401-406. http://dx.doi.org/10.1111/j.1439-0426.2009.01259.x

Bagenal, T.B., Tesch, F.W., 1978. Age and growth. In: Bagenal, T. (Ed.), Methods for Assessment of Fish Production in Fresh Waters, 3rd Ed. IBP Handbook No. 3, Blackwell Science Publications Ltd., Oxford, p.101-136.

Bendiksen, E., Jobling, M., Arnesen, A.M., 2002. Feed intake of Atlantic salmon parr Salmo salar L. in relation to temperature and feed composition. Aquacult. Res., 33(7): 525-532. http://dx.doi.org/10.1046/j.1365-2109.2002.00737.x

Bjornsson, B., Steinarsson, A., Oddgeirsson, M., 2001. Optimal temperature for growth and feed conversion of immature cod (Gadus morhua L.). ICES J. Mar. Sci., 58(1): 29-38. http://dx.doi.org/10.1006/jmsc.2000.0986

Blanco, S., Romo, S., Villena, M.J., et al., 2003. Fish communities and food web interactions in some shallow Mediterranean lakes. Hydrobiologia, 506-509(1-3): 473-480. http://dx.doi.org/10.1023/B:HYDR.0000008583.05327.da

Braga, F.M.S., 1986. Estudo entre fator de condição e relação pesocomprimento para alguns peixes marinhos. Rev. Bras. de Biol., 46(2):339-346 (in Spanish).

Brown, J.A., Pepin, P., Methven, D.A., et al., 1989. The feeding, growth and behaviour of juvenile cod, Gadus morhua L., in cold environments. J. Fish Biol., 35(3): 373-380.

http://dx.doi.org/10.1111/j.1095-8649.1989.tb02989.x

Burton, M.L., 2002. Age, growth and mortality of mutton snapper, Lutjanus analis, from the east coast of Florida, with a brief discussion of management implications. Fish. Res., 59(1-2):31-41. http://dx.doi.org/10.1016/S0165-7836(02)00007-3

Byström, P., Anderson, J., Kiessling, A., et al., 2006. Size and temperature dependent foraging capacities and metabolism: consequences for winter starvation mortality in fish. Oikos, 115(1):43-52.

http://dx.doi.org/10.1111/j.2006.0030-1299.15014.x

Castillo-Vargasmachuca, S., Ponce-Palafox, J., García-Ulloa, M., et al., 2012. Effect of stocking density on growth performance and yield of subadult pacific red snapper cultured in floating sea cages. N. Am. J. Aquacult., 74(3): 413-418.

http://dx.doi.org/10.1080/15222055.2012.676002
Castillo-Vargasmachuca, S., Ponce-Palafox, J.T., RodríguezChávez, G., et al., 2013. Effects of temperature and salinity on growth and survival of the Pacific red snapper Lutjanus peru (Pisces: Lutjanidae) Juvenile. Latin Am. J. Aquacult. Res., 41(5):1013-1018.

http://dx.doi.org/10.3856/vol41-issue5-fulltext-22

Clark, D.S., Brown, J.A., Goddard, S.J., et al., 1995. Activity and feeding behaviour of Atlantic cod (Gadus morhua) in sea pens. Aquaculture, 131(1-2):49-57.

http://dx.doi.org/10.1016/0044-8486(94)00222-A

Crawford, R., 1993. World record game fishes 1993. The International Game Fish Association, Pompano Beach, Florida.

da Costa, D.P., Leme, F.D.O.P., Takata, R.T., et al., 2016. Effects of temperature on growth, survival and physiological parameters in juveniles of Lophiosilurus alexandri, a carnivorous neotropical catfish. Aquacult. Res., 47(6): 1706-1715. http://dx.doi.org/10.1111/are.12594

Das, S.K., De, M., Ghaffar, M.A., 2014a. Length-weight relationship and trophic level of hard-tail scad Megalaspis cordyla. Sci. Asia, 40(5):317-322. http://dx.doi.org/10.2306/scienceasia1513-1874.2014.40.317

Das, S.K., Ghaffar, M.A., Bakar, Y., et al., 2014b. Xradiographic observations of food passage and nutrient absorption along the alimentary tract of archerfish, Toxotes jaculatrix. Bull. Mar. Sci., 90(4):903-919. http://dx.doi.org/10.5343/bms.2013.1073

De, M., Ghaffar, M.A., Das, S.K., 2013. Temperature effect on gastric emptying time of hybrid grouper (Epinephelus sp.). THE 2014 UKM FST POSTGRADUATE COLLOQUIUM: Proceedings of the Universiti Kebangsaan Malaysia, Faculty of Science and Technology 2014 Postgraduate Colloquium. AIP Conference Proceedings, 1614: 616-618. http://dx.doi.org/10.1063/1.4895273

Ecoutin, J.M., Albaret, J.J., Trape, S., 2005. Length-weight relationships for fish populations of a relatively undistributed tropical estuary: the Gambia. Fish. Res., 72(2-3): 347-351. http://dx.doi.org/10.1016/j.fishres.2004.10.007

Elliot, J.M., 1994. Quantitative Ecology and the Brown Trout. Oxford University Press, Oxford.

Englund, G., Öhlund, G., Hein, C.L., et al., 2011. Temperature dependence of the functional response. Ecol. Lett., 14(9): 914-921. http://dx.doi.org/10.1111/j.1461-0248.2011.01661.x

Fonds, M., Cronie, R., Vethaak, A.D., et al., 1992. Metabolism, food consumption and growth of plaice (Pleuronectes platessa) and flounder (Platichthys flesus) in relation to fish size and temperature. Neth. J. Sea Res., 29(1-3): 127-143. http://dx.doi.org/10.1016/0077-7579(92)90014-6

Froese, R., 2006. Cube law, condition factor and weight-length relationships: history, meta-analysis and recommendations. J. Appl. Ichthyol., 22(4):241-253. 
http://dx.doi.org/10.1111/j.1439-0426.2006.00805.x

Froese, R., Pauly, D., 2012. FishBase World Wide Web electronic publication, Version (09/2010). Available from http://www.fishbase.org [Accessed on Oct. 15, 2015].

Fulton, T.W., 1904. The rate of growth of fishes. Twentysecond Annual Report, Part III. Fishes Board of Scotland. Edinburgh, p.141-241.

Garduño-Dionate, M., Unzueta-Bustamante, M.L., HernándezMartínez, M., et al., 2010. Crecimiento de huachinangos juveniles silvestres (Lutjanus Peru) en un encierro de engorda en Puerto Vicente Guerrero, Guerrero. Cienc. Pesq., 18(1):93-96 (in Spanish).

Gayanilo, F.C., Pauly, D., 1997. FAO ICLARM stock assessment tools (FiSAT): references manual. FAO Computerized information series: 262.

Hallaraker, H., Folkvord, A., Stefansson, S.O., 1995. Growth of juvenile halibut (Hippoglossus hippoglossus) related to temperature, day length and feeding regime. Neth. J. Sea Res., 34(1):139-147. http://dx.doi.org/10.1016/0077-7579(95)90022-5

Harrison, T.D., 2001. Length-weight relationships of fishes from South African estuaries. J. Appl. Ichthyol., 17(1): 46-48. http://dx.doi.org/10.1046/j.1439-0426.2001.00277.x

Helmuth, B., Broitman, B.R., Yamane, L., et al., 2010. Organismal climatology: analyzing environmental variability at scales relevant to physiological stress. J. Exp. Biol., 213(6):995-1003. http://dx.doi.org/10.1242/jeb.038463

Imsland, A.K., Foss, A., Sparboe, L.O., et al., 2006. The effect of temperature and fish size on growth and food efficiency ratio of juvenile spotted wolffish. J. Fish Biol., 68(4):1107-1122. http://dx.doi.org/10.1111/j.0022-1112.2006.00989.x

Imsland, A.K., Björnsson, B.T., Gunnarsson, S., et al., 2007. Temperature and salinity effects on plasma insulin-like growth factor-I concentrations and growth in juvenile turbot (Scophthalmus maximus). Aquaculture, 271(1-4): 546-552. http://dx.doi.org/10.1016/j.aquaculture.2007.07.007

Jobling, M., 1995. Fish Bioenergetics. Chapman and Hall, London.

Johnston, I.A., 2006. Environment and plasticity of myogenesis in teleost fish. J. Exp. Biol., 209(12):2249-2264. http://dx.doi.org/10.1242/jeb.02153

Jonassen, T.M., Imsland, A.K., Stefansson, S.O., 1999. The interaction of temperature and size on growth of juvenile Atlantic halibut. J. Fish Biol., 54(3):556-572. http://dx.doi.org/10.1111/j.1095-8649.1999.tb00635.x

Joyeux, J.C., Giarrizzo, T., Macieira, R.M., et al., 2009. Length-weight relationships for Brazilian estuarine fishes along a latitudinal gradient. J. Appl. Ichthyol., 25(3): 350-355. http://dx.doi.org/10.1111/j.1439-0426.2008.01062.x

Jun, Q., Pao, X., Haizhen, W., et al., 2012. Combined effect of temperature, salinity and density on the growth and feed utilization of Nile tilapia juveniles (Oreochromis niloticus). Aquacult. Res., 43(9):1344-1356. http://dx.doi.org/10.1111/j.1365-2109.2011.02938.x

Kooijman, S.A.L.M., 2000. Dynamic energy and mass budget in biological systems. Cambridge University Press, Cambridge.

Lagler, K.F., 1966. Freshwater fishery biology. W.C. Brown Co., Dubuque, Iowa, p.421.

le Cren, E.D., 1951. The length-weight relationship and seasonal cycle in gonad weights and condition in the perch (Perca fluviatilis). J. Anim. Ecol., 20(2):201-219.

Masood, Z., Farooq, R.Y., 2010. Length-weight relationship and condition and relative condition parameters of Lutjanus species of the family Lutjanidae collected from Karachi fish harbor, Pakistan. Int. J. Biol. Biot., 7(4):505-509.

Mazumder, S.K., Ghaffar, M.A., Das, S.K., 2015a. The effect of temperature on gastric emptying time of Malabar blood snapper (Lutjanus malabaricus, Bloch \& Schneider 1801) using X-radiography technique. AIP Conference Proceedings, Selangor, Malaysia, 1678(020032):1-4. http://dx.doi.org/10.1063/1.4931217

Mazumder, S.K., De, M., Mazlan, A.G., et al., 2015b. Impact of global climate change on fish growth, digestion and physiological status: developing a hypothesis for cause and effect relationships. J. Water Clim. Change, 6(2): 200-226.

http://dx.doi.org/10.2166/wcc.2014.146

Mims, S.K., Knaub, R.S., 1993. Condition factors and lengthweight relationships of Pond-cultured paddlefish Polyodon spathula with reference to other morphogenetic relationships. J. World Aquacult. Soc., 24(3):429-433. http://dx.doi.org/10.1111/j.1749-7345.1993.tb00176.x

Nanton, D.A., Lall, S.P., McNiven, M.A., 2001. Effects of dietary lipid level on liver and muscle lipid deposition in juvenile haddock, Melanogrammus aeglefinus L. Aquacult. Res., 32(Suppl. 1):225-234. http://dx.doi.org/10.1046/j.1355-557x.2001.00019.x

Oni, S.K., Olayemi, J.Y., Adegboye, J.D., 1983. Comparative physiology of three ecologically distinct fresh water fishes, Alestes nurse Ruppell, Synodontis schall Bloch and S. schneider and Tilapia zilli Gervais. J. Fish Biol., 22(1):105-109. http://dx.doi.org/10.1111/j.1095-8649.1983.tb04730.x

Pakoa, K., 1998. Vital statistics of marine fishes of Vanuatu. Naga, ICLARM Q., 21(3):27-29.

Petrakis, G., Stergiou, K.I., 1995. Weight-length relationships for 33 fish species in Greek waters. Fish. Res., 21(3-4):465-469. http://dx.doi.org/10.1016/0165-7836(94)00294-7

Rosenlund, G., Skretting, M., 2006. Worldwide status and perspectives on gadoid culture. ICES J. Mar. Sci., 63(2):192-196. http://dx.doi.org/10.1016/j.icesjms.2005.11.012

Safran, P., 1992. Theoretical analysis of the weight-length relationships in the juveniles. Mar. Biol., 112(4):545-551. 
http://dx.doi.org/10.1007/BF00346171

Santamaría-Miranda, A., Elorduy-Garay, J.F., Villalejo-Fuerte, M., et al., 2003. Desarrollo gonadal y ciclo reproductivo de Lutjanus peru (Pisces: Lutjanidae) en Guerrero, México. Int. J. Trop. Biol. Cons., 51(2):489-502 (in Spanish).

Sarkar, U.K., Khan, G.E., Dabas, A., et al., 2013. Length weight relationship and condition factor of selected freshwater fish species found in River Ganga, Gomti and Rapti, India. J. Environ. Biol., 34:951-956.

Simon, K.D., Bakar, Y., Samat, A., et al., 2009. Population growth, trophic level, and reproductive biology of two congeneric archer fishes (Toxotes chatareus, Hamilton 1822 and Toxotes jaculatrix, Pallas 1767) inhabiting Malaysian coastal waters. J. Zhejiang Univ.-Sci. B (Biomed. \& Biotechnol.), 10(12):902-911. http://dx.doi.org/10.1631/jzus.B0920173

Simon, K.D., Bakar, Y., Temple, S.E., et al., 2010a. Morphometric and meristic variation in two congeneric archer fishes Toxotes chatareus (Hamilton 1822) and Toxotes jaculatrix (Pallas 1767) inhabiting Malaysian coastal waters. J. Zhejiang Univ.-Sci. B (Biomed. \& Biotechnol.), 11(11):871-879. http://dx.doi.org/10.1631/jzus.B1000054

Simon, K.D., Mazlan, A.G., Samat, A., et al., 2010b. Size, growth and age of two congeneric archer fishes (Toxotes jaculatrix Pallas, 1767 and Toxotes chatareus Hamilton 1822). Sains Malaysiana, 39(5):697-704.

Simon, K.D., Mazlan, A.G., Bakar, Y., et al., 2012. Aspects of the reproductive biology of two archer fishes Toxotes chatareus, (Hamilton 1822) and Toxotes jaculatrix (Pallas 1767). Environ. Biol. Fish., 93(4):491-503. http://dx.doi.org/10.1007/s10641-011-9944-6

Temming, A., Herrmann, J.P., 2001. Gastric evacuation of horse mackerel. II. The effects of different prey types on the evacuation model. J. Fish Biol., 58(5):1246-1256. http://dx.doi.org/10.1111/j.1095-8649.2001.tb02283.x

Thomas, J., Venus, S., Kurup, B.M., 2003. Length-weight relationship of some deep-sea fish inhabiting continental slope beyond $250 \mathrm{~m}$ depth along west coast of India. Naga, 26(2):17-21.

Treasurer, J.W., Hastie, L.C., Hunter, D., et al., 2006. Effects of (Margaritifera margaritifera) glochidial infection on performance of tank-reared Atlantic salmon (Salmo salar). Aquaculture, 256(1-4):74-79.

http://dx.doi.org/10.1016/j.aquaculture.2006.02.031

Willing, R.S., Pender, P.J., 1989. Length-weight relationships for 45 species of fish and three invertebrates from Australia's Northern Prawn Fishery. Technical Bulletin. Northern Territory Department of Primary Industry and Fisheries, Australia, Darwin, Australia.

Wootton, R.J., 1990. Ecology of Teleost Fishes. Chapman and Hall, Upper Saddle River, New Jersey, USA.

Yanagawa, H., 1994. Length-weight relationship of Gulf of Thailand fishes. Naga, ICLARM Q., 17(4):48-52.

Zar, J.H., 1996. Biostatistical Analysis, 3rd Ed. Prentice Hall, Upper Saddle River, New Jersey, USA.

Zhang, G., Yin, S., Wang, Y., et al., 2015. The effects of water temperature and stocking density on survival, feeding and growth of the juveniles of the hybrid yellow catfish from Pelteobagrus fulvidraco $($ ( $) \times$ Pelteobagrus vachelli $(\hat{0})$. Aquacult. Res., online.

http://dx.doi.org/10.1111/are.12734

\section{中文概要}

\section{题 目: 温度和喂食影响摩拉吧笛鲷体长体重关系和肥满} 度的研究

目 的: 分析水温度和喂食对摩拉吧笛鲖体长体重关系和 肥满度的影响。

创新点: 本研究采用条件可控的流通式海水系统, 对摩拉 吧笛鲷的体长体重关系和肥满度进行研究。

方 法: 本研究使用流通式海水系统在实验室中实施, 选 取 4 种不同温度 (22、26、30 和 $\left.34{ }^{\circ} \mathrm{C}\right)$ 和 2 种 饮食条件（商业颗粒和自然虾米）, 每天喂食 2 次, 比较鲖鱼体长体重关系和肥满度差异。

结 论: 结果表明, 摩拉吧笛鲷的最好饲养条件是 $30^{\circ} \mathrm{C}$, 而喂食种类对摩拉吧笛鲷的生长和肥满度的影 响没有显著差异。本研究提供了温度和饮食对摩 拉吧笛鲖体长体重关系和肥满度影响的基本信 息, 可用于该物种的生理状态评估。

关键词: 体长体重关系; 肥满度; 温度; 生长; 水产养殖; 鲷鱼 